\title{
The Impact of Language and Skills Training on Immigrants' Lives
}

\section{Ping Wong, Patricia Duff, and Margaret Early}

This study is a qualitative exploration of the experiences of immigrants who completed a health care aide training program that combined occupational skills and ESL training. The focus was the employment barriers and personal benefits associated with program completion. Data were collected through structured interviews with nine participants, eight of whom were women, which were then transcribed and analyzed for central themes. The interview data were supplemented with document data consisting of information from application forms and intake assessment tests. The findings revealed that participation in the training program had a major impact on the employment, identities, and settlement of program participants. The skills and language training improved the employment prospects of the individuals, although many had to overcome such employment barriers as the need to work on call, conflicts between domestic responsibilities and work outside the home, and transportation limitations. Many participants also spoke of the importance of learning job-search skills and the personal significance of having an occupational identity. Finally, successful completion of the program increased the self-confidence and autonomy of the individuals, which in turn aided their settlement and integration into Canadian society. The article concludes with recommendations for future research in this area, as well as pedagogical interventions to assist participants with their ongoing language learning, job aspirations, and settlement.

Cette recherche est une étude qualitative sur les expériences d'immigrants qui ont complété un programme d'aide-soignante qui jumelait une formation sur les compétences professionnelles et de l'enseignement en ALS. La recherche a ciblé les obstacles à l'emploi et les avantages personnels que connaissaient ceux qui complétaient le programme. Neuf participants, dont huit femmes, ont participé à des entrevues structurées qui ont été transcrites et analysées pour en retirer les thèmes principaux. À ces données ont été ajoutées des informations recueillies de formulaires de demande et d'évaluations initiales. Les résultats indiquent que la participation au programme de formation a eu un impact très important sur l'emploi, l'identité et l'établissement des participants. D'abord, les habiletés et la compétence linguistique ont augmenté les possibilités d'emploi des participants, quoique plusieurs aient à surmonter des obstacles à l'emploi tels que le besoin de travailler sur appel, des conflits entre les responsabilités à la maison et le travail à l'extérieur, ainsi que des contraintes liées au transport. Ensuite, plusieurs participants ont également évoqué l'importance de développer des habiletés de 
recherche d'emploi et l'impact personnel d'avoir une identité professionnelle. Dernièrement, le fait de réussir le programme a augmenté la confiance en soi et l'autonomie des individus, ce qui a contribué à leur établissement au Canada et leur intégration à la société. Les auteurs terminent l'article en présentant des recommandations quant à la recherche dans le domaine et quant aux interventions pédagogiques qui aideraient les participants avec leur apprentissage linguistique continu, leurs buts de carrière et leur établissement.

\section{Introduction}

The nature of workplace language and communication and the needs of immigrants and other first- and second-language speakers either entering the work force or being retrained for new kinds of work have received increasing attention in recent years (Duff \& Labrie, 2000; Roberts, Davies, \& Jupp, 1992). In English-dominant countries such as Canada, the importance of English-language training programs for immigrants' settlement and socioeconomic advancement is indisputable (Boyd, 1992; Burnaby, 1992). However, relatively little research has examined the actual impact of such programs on the lives of immigrants and their ongoing settlement process. Also lacking is qualitative information about the benefits of participation in occupational skills and English training programs from the perspectives of immigrants themselves $(\mathrm{Li}, 2000)$. Therefore, the rationale for the present study was to gather qualitative data through interview narratives in order to understand better the experiences of immigrants in a training program and to examine the impact of participation in such a program on their private and public lives, namely, in terms of their changing identities, family and social relationships, employment, and settlement and integration in Canadian society.

This was part of a larger study that examined the experiences of a total of 20 participants in Home Support (HS) / Resident Care Attendant (RCA) programs in one immigrant settlement agency in Western Canada at various points in their program: before, during, and after its completion (Duff, Wong, \& Early, 2000). Whereas Duff et al. describe the experiences of individuals during and immediately following their programs and practicum in terms of language socialization processes, the present study focuses on individuals who completed programs one to two years earlier and examines employment and settlement issues in more depth (see also Wong, 1998). The study employed qualitative research methods, especially interviews and document analysis, to understand the linguistic socialization and identity transformations of immigrants learning ESL and nursing skills in order to work in health care professions. We were especially interested in the processes by which minority women become more integrated in Canadian society because they represent a potentially disadvantaged, marginalized, and at- 
because they represent a potentially disadvantaged, marginalized, and atrisk group as a result of such factors as race, gender, home-culture expectations, immigrant status, and reduced or delayed opportunities to learn English (Boyd, 1992; Wittebrood \& Robertson, 1991). The present study explored the experiences of nine participants (8 women and 1 man), two of whom had graduated from an HS training program in 1996, and seven from a combined HS/RCA program in 1997. Both programs prepared individuals to work in entry-level positions in health care, primarily providing care to the elderly. Graduates from the HS program were certified only to work in private homes and group homes, whereas graduates from the combined program were also certified to work in long-term care facilities. This study is somewhat unique because it investigates the outcomes of an ESL-skills program and has participants reflect on their educational experiences and employment retrospectively over a period of several years. Thus the study is not an evaluation of the program, but rather an account of participants' experiences and an analysis of common themes that emerged.

\section{Background}

Four main categories of previous research of relevance to the present study include the following: (a) immigrant women and employment; (b) access to vocational and language training programs; (c) vocational ESL (VESL) and English for the workplace; and (d) immigrant settlement, socialization, and identity issues. We have included the first category for reasons given above regarding the marginalization of many immigrant women from mainstream society and also because most of the health care workers in HS/RCA, as in the present study, are women. Below, we summarize the findings of work in these four areas (see Figure 1).

First, previous studies and reports have identified the importance of immigrant women in the Canadian labor market and their contributions to their family income. A number of authors have discussed the disadvantaged position of female immigrant workers in terms of job status and income (Boyd, 1992; Lee, 1999; Ng \& Estable, 1987). According to Boyd, immigrant women, particularly those from Asian and Southern European countries, are characterized by lower education, concentration in the lower echelons of service and processing occupations, and lower incomes. Furthermore, Lee emphasized the particular disadvantages of "racialized" immigrant women both when they are of working age and perhaps even more so when they are elderly and lack sufficient pension and other benefits. In addition, many immigrant women work a "double day" as they bear primary responsibility for household work and child care, and many do shift or night work so that they can juggle household and child care duties. Other authors have focused on the difficulties faced by immigrant women in the workplace and their lack of opportunities for upward mobility in the labor market; this situation may 


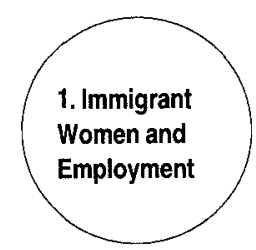

- importance of immigrant women in the Canadian labor market

- concentration in low-status, low-paying jobs

- barriers to improving job situation

- need for training

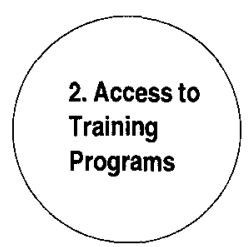

- barriers to access: systemic, organizational, personal

- importance of training to improve social and economic position

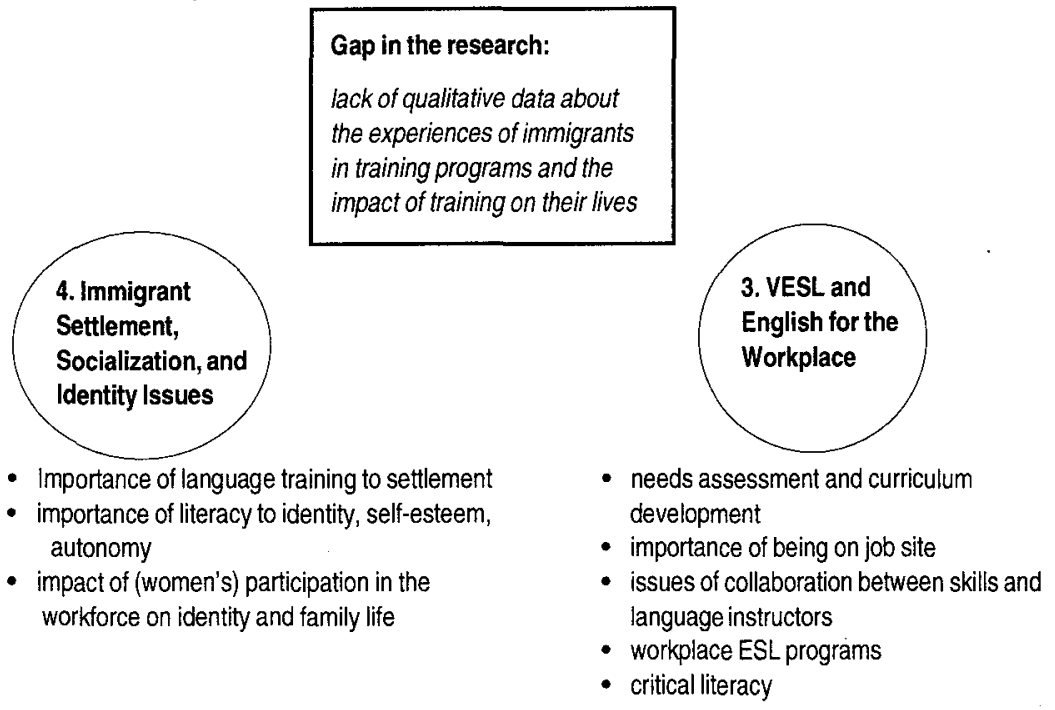

Figure 1. Overview of previous research (adapted from Wong, 1998).

be further reinforced by conservative social and cultural pressures from both outside and within immigrant communities that assume in-group solidarity, conformity, and loyalty, and that militate against moving out and up to higher levels of responsibility and authority (Goldstein, 1997). The literature, therefore, identifies the need for training to improve the long-term socioeconomic position of immigrant women and not just to equip them for short-term work that fulfills the immediate "requirements of industry" and little else (Jackson, 1991).

Second, in recent years a number of studies have focused on the issue of immigrant women's access to language and occupational programs (Burnaby, 1992; Cumming \& Gill, 1992; Rockhill \& Tomic, 1994; Tisza, 1997). Various types of barriers to accessing training programs have been identified such as eligibility barriers, organizational barriers, and social and personal 
barriers. The issue of access is especially crucial given the relationship between participation in training programs and immigrants' enhanced social and economic wellbeing. Some specific examples of access barriers include eligibility requirements that exclude many women who are classified as dependants, long waiting lists, lack of program supports (e.g., child care), funding sources for training, and personal barriers such as low self-confidence.

Third, another body of related literature deals with teaching VESL and English for the workplace. This research examines how best to help adult ESL learners acquire the language and literacy skills needed for work. For example, Holliday (1995), Svendsen and Krebs (1984), and Frank (2000) discussed the importance of needs assessment. Others have focused on the issue of collaboration between the language and skills professionals in instruction and assessment (Platt, 1993; Stapp, 1998). Goldstein (1994, 1997), Harper, Peirce, and Burnaby (1996), and Katz (2000) have examined workplace English programs from a more critical perspective, exploring global changes in work and corresponding ideologies of "competence" and "skills" that now place different expectations on workers than in the past through a form of sociolinguistic engineering (Gee, Hull, \& Lankshear, 1996). Drawing on this and other work in critical workplace literacy(ies), Bell (2000) examined the literacy challenges that exist for ESL and self-identified native speakers of English in technical job-training programs and the teaching strategies that might facilitate students' learning and more critical engagement with texts.

The fourth category of literature pertinent to the present study deals with immigrant settlement, socialization, and identity issues. Tollefson (1985), for example, identified the importance of language training to the settlement process, and Rockhill (1991) discussed the importance of literacy in relation to identity, self-esteem, and autonomy. Eastmond (1993) examined how women's participation in the work force affects roles and relationships at home. Duff et al. (2000) examined workplace language learning and performance in terms of interpersonal and intercultural negotiation among caregivers and residents. They also viewed immigrants' adaptation to a new language and culture and the appropriation of new skills, practices, and identities as an ongoing process of socialization mediated through language and interaction with others in the target community. Finally, Norton's (2000) in-depth study of the relationship between identity and language learning in the lives of five immigrant women in Canada examined the power relations and other social factors that either facilitated or impeded the women's integration into English-speaking society and their access to, and participation in, anglophone social networks.

What has been lacking in most previous studies across these four areas is qualitative research on the actual impact of combined skills and language 
training programs on the personal and social lives of participants and their subsequent employment prospects. That is, therefore, the aim of this study, and the research questions guiding this study are framed accordingly.

\section{The Study}

\section{Research Questions}

The following set of research questions was addressed in the study:

1. What is the impact of completing an ESL and skills program for home support and resident care on individuals' subsequent employment?

2. What is the impact of such a program on individuals' perceptions of their English language abilities and of their social interactions with people in both public and private spheres? By public we mean workplace and public institutions such as schools and government offices, and by private we mean family, friends, and their personal social community.

3. What is the impact of ESL and skills training and employment on individuals' identities and settlement in Canada?

\section{Context and Methodology}

The site of the study was the Immigrant Settlement Agency, which is referred to as ISA (a pseudonym). ISA is a not-for-profit immigrant settlement agency in Western Canada. The mission of this organization is to identify the needs of immigrants and refugees and to develop and deliver effective programs and services to meet those needs. ISA supports the settlement, training, and integration of immigrants and refugees through counseling services, employment services, and a variety of language training and combined occupational skills and language training programs. The organization is divided into two branches, a training institute and a settlement house. The location of most of the training programs is the training institute; however, the programs in this study took place at the settlement house.

The HS and combined HS/RCA training programs prepared individuals to help elderly people in daily routines. Occupational skills were taught for four hours every morning by a registered nurse, and ESL was taught for 2.5 hours every afternoon by an ESL teacher. In the occupational skills class, the students were taught health care work skills such as home maintenance, lifts and transfers, personal care skills, health and healing, and anatomy and physiology; in the ESL class the students worked on improving their general English skills as well as learning English for work in health care and English for the job-search process, including interview techniques. The program was full time, and lasted seven months. The students also had two off-site practica for a total of nine weeks (see Duff et al., 2000, for details). 


\section{Recruitment of Research Participants from Past Cohorts}

In order to recruit participants from past cohorts of program graduates, letters were sent out on our behalf by the program manager at ISA in February 1998 to all graduates from the 1996 and 1997 programs. The program manager personally knew all the former students who were contacted, but assured them that their participation was voluntary. We followed up this notification by telephone. Two graduates from the 1996 HS program and seven from the 1997 RCA program agreed to participate in the study. In general, it was more difficult to contact graduates from the 1996 program as many had moved in the meantime. The participants are described more fully below.

\section{Data Collection Methods}

Data were collected by means of individual, semistructured interviews that lasted from 30 to 75 minutes each. All interviews were audiotaped. Four of the interviews were conducted by telephone, and five were conducted in person. Although ideally all would have been conducted in the same manner, the participants determined the time, medium, and site of the interviews. For some with young children, irregular work schedules, or homes far from ISA, telephone interviews represented the most viable and least imposing option. ${ }^{1}$ Four of the in-person interviews took place in a classroom at ISA and one at a participant's home. All the interviews were transcribed and analyzed for dominant themes.

\section{Participant Profiles}

This section provides background information about each participant. As Table 1 shows, eight of the nine participants were female, a ratio that roughly reflects the demographics in such programs. In a class of 16 to 20 students, for example, there are usually only one or two men. The participants' countries of origin varied. The majority were from Asia but there were also individuals from Europe, Latin America, and Africa. Most were landed immigrants who had been in Canada for fewer than 10 years; however, two of the participants, Alberto and Anna, were Canadian citizens who had been in Canada for over 20 years. The participants' ages ranged from their early 30 s to late 40 s; most were married and had children. In terms of education and work history, the nine individuals represented a range of experiences. Two, Anna and Rita, had finished grade 10 in their country of origin; most had completed secondary school and had some additional postsecondary education or training. Participants also demonstrated a wide range in English proficiency on entry into the program, from low intermediate to advanced. As is commonly the case, most of the participants worked in lower-status jobs following immigration than those held before. Despite their 
Table 1

Description of Research Participants

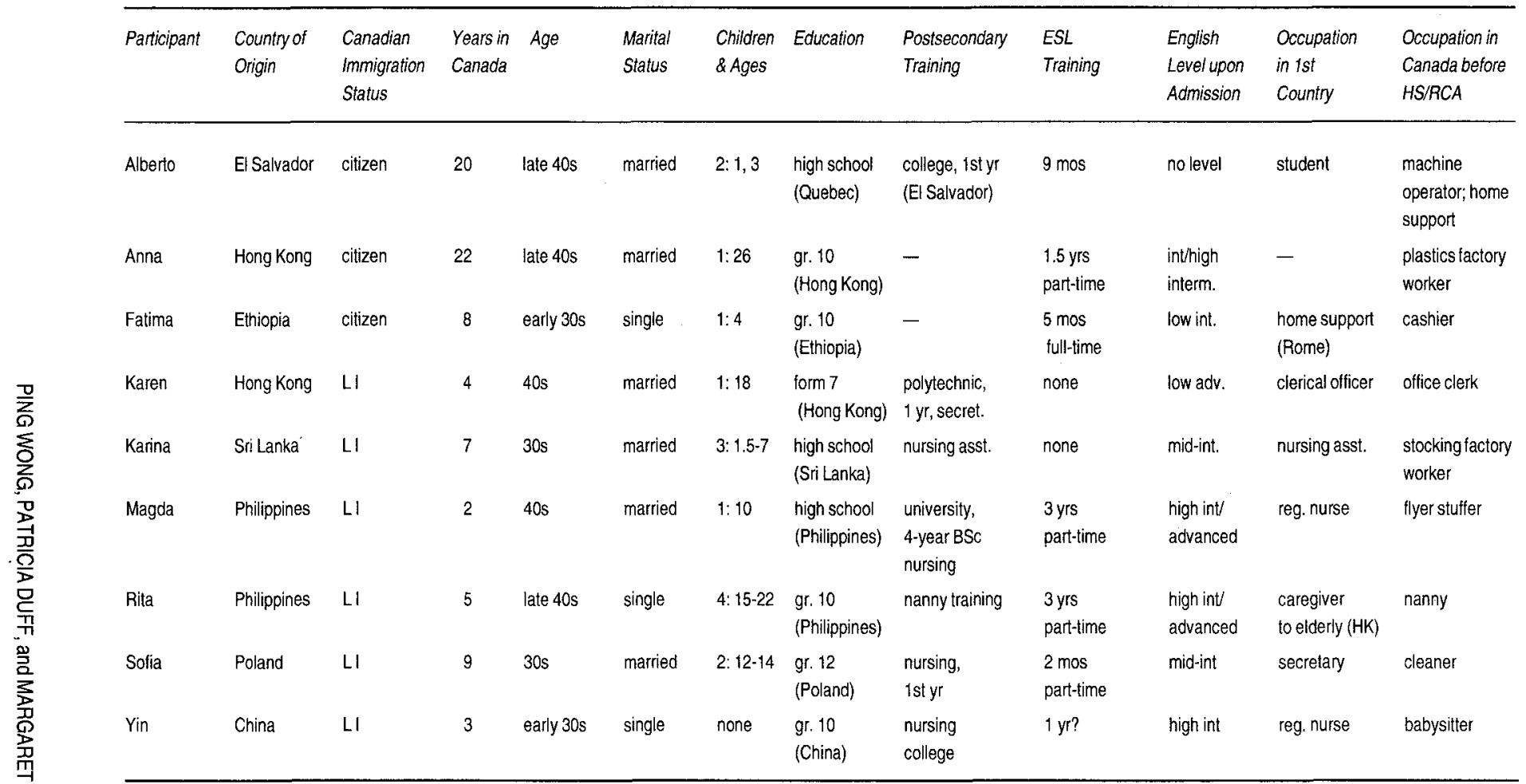

Note: $L . \mathrm{I}=$ landed immigrant. 
many differences, however, the participants shared some degree of work experience in health care or a longstanding interest in that field.

Because one of the aims of this study was to understand lived experiences and perspectives and to present data from holistic, emic (insider) perspectives as well as our own analyses, brief individual profiles allow readers to better understand the contexts of participants' lives and experiences (pseudonyms are used throughout). In the following section participants are grouped in three categories based on how much previous employment experience they had in the health care field, an important factor in relation to their perspectives, experiences, expectations, and goals. We then discuss the findings of the study in terms of employment, training, and personal issues.

\section{Foreign-Trained Nurses (Magda and Jin)}

Two of the participants, Magdalena (Magda) and Yin, were both trained as nurses in their countries of origin. Magda completed three years of preparatory training for nursing and four years of nursing in two universities in the Philippines, graduating with a BSc in nursing in the mid-1970s. Madga worked for about four years as a hospital nurse in the Philippines before going to Saudi Arabia, where she worked as a nurse for 12 years. Before coming to Canada she returned to the Philippines and worked there for another two years. Magda's occupation as a nurse was a major part of her identity, and it had been difficult for her to arrive in Canada and to find that her qualifications and extensive experience were not recognized. She had been in Canada since 1995 with her husband and 10-year-old son. Before enrolling in the RCA program, Magda had a job stuffing flyers in envelopes, and she was discouraged about her employment prospects. It was important to her ultimately to work as a registered nurse again. ${ }^{2}$

I was so desperate when I came here that I cannot practice my profession with, I mean, the length of experience that I had before.... I was working out of line of my profession and it's really frustrating... Nursing has been my life already. I mean, I've been working as a nurse for more than 18 years, so it's really my life now.

Like Magda, Yin had many years of experience as a nurse and she too aspired to become a registered nurse in Canada. Yin had attended a threeyear nursing program in Beijing and worked for six years as an operating room nurse in a Beijing hospital. Unlike Magda, however, Yin had immigrated to Canada on her own and had been here for about four years. On arrival in Canada she enrolled in ESL courses to upgrade her English skills in order to apply for a training program. Before joining the RCA program she had worked in Canada as a babysitter. At the time of our interview, in addition to working full time in a long-term care facility, Yin was upgrading 
her nursing skills by taking a course in dementia care at a local community college.

\section{Participants with Experience in Health Care (Sofia, Karina, Fatima, Rita, and Alberto)}

A number of the other participants also had some past work experience in the health care field, although not as extensive as that of Magda and Yin. This experience was instrumental in the participants' desire to receive training and find employment in this field. Sofia and Karina were both in the HS program, whereas the others were all in the RCA program. Both had schooling in health care in their countries of origin (Poland and Sri Lanka), and Karina had work experience as a nursing assistant in Sri Lanka, but neither had any related work experience in Canada. Sofia had studied one year of psychiatric nursing in Poland, which she was unable to complete as she needed to obtain work. After being employed as a secretary, she got married and then stayed home. She had lived in Canada with her husband and two teenaged children for nine years and had mainly found work as a cleaner. At the time of the interview Sofia had not been able to find employment as a health care worker. When looking for employment as an HS worker, she faced many barriers related to transportation limitations and conflicts between family responsibilities and on-call work. However, she did not regret taking the program as it gave her much personal satisfaction to complete the program and helped her to develop skills that were useful outside of the work context, especially English skills.

Karina had completed training to be a nursing aide in Sri Lanka and worked there in that capacity for seven years before immigrating to Canada. She had been in Canada for seven years, and just before taking the program had relocated to Western Canada from Montreal, where she worked in a factory as an assembler. One dominant theme in Karina's life was her role as the mother of young children. During the HS program, she became pregnant with her third child and thus had not been able to look for work after she graduated. At the time of our interview Karina was in the process of getting her driver's license and was hopeful about finding an HS job. She was also attending an advanced-level ESL class and hoped to some day get her grade 12 equivalency. Karina talked about the difficulties accompanying their relocation to Western Canada, especially finding employment.

Fatima, Rita, and Alberto had all worked in HS, Fatima and Rita overseas and Alberto in Montreal. Originally from Ethiopia, Fatima had been a live-in HS worker in Rome before coming to Canada nine years earlier. She first lived and worked for about four years in Toronto before relocating to Western Canada because of domestic problems. She was now the single parent of a 4-year-old son. Fatima had participated in the New Start Program, one of ISA's pre-employment programs, and after its completion was 
referred to the RCA training program. At the time of our interview Fatima had not been able to find work, despite doing many months of volunteer work to get Canadian work experience. This situation was discouraging for Fatima because finding employment was especially vital for her as a single parent.

Rita was a soft-spoken, mature woman from the Philippines. Before coming to Canada in the early 1990s, she worked as a domestic helper and companion to an elderly lady in Hong Kong. She really enjoyed this work, and therefore applied to the program on receiving her landed immigrant status. In Canada she worked as a nanny and housekeeper. She was a widow and had four children, ages 15 to 22, back in the Philippines. At the time of our meeting Rita was working part time for an HS agency. She expressed the desire for more work but said that it was difficult to find.

Like Karina, Alberto had also relocated to Western Canada from Montreal. Alberto was one of three participants who were Canadian citizens. Originally from El Salvador, Alberto had lived in Canada 20 years and presently lived with his wife and two preschool-aged children. It was in Montreal that Alberto started doing some work in HS on weekends, in addition to his full-time job as a factory machine operator. On moving to Western Canada Alberto decided that he wanted to change occupations and to find work as a health care worker. Unfortunately, it was not as easy to find work here as it was in Montreal because of certification requirements. Alberto took some ESL courses to upgrade his English as he had completed high school in French in Montreal and had spoken mainly French. Just a few months before our meeting he was offered a permanent part-time position at a French-speaking facility.

\section{Participants Seeking a New Occupation (Karen and Anna)}

For both Karen and Anna, taking the RCA program represented a complete change in occupation. Neither had worked in health care before, that is, as caregivers. However, Karen was an administrator in a hospital for two years in Hong Kong, so she was familiar with the work environment. She explained that she had always been interested in nursing, but after high school had decided on a different career path. She now wanted to pursue her earlier interest. Karen had been in Canada for four years and had worked as an office clerk in two Chinese companies before enrolling in the RCA program. She appeared to be comfortable and confident living in Canada. It had not been difficult for her to find work, and she expressed satisfaction with her work situation. She lived with her husband and 18-year-old son and seemed to have a strong social network consisting of her family, friends, and religious community.

Lastly, Anna, like Alberto, had been living in Canada for over 20 years with her husband and grown son. She started working soon after immigrat- 
ing to Canada from Hong Kong and was employed by one plastics company for 15 years before being laid off due to the company's move to Montreal. For Anna, taking and completing the course was a major challenge, as she was almost 50 years old and had last been in school when she was in grade 10 . Completing the course was a major accomplishment for her, and she surprised herself and others by finishing the program successfully. Anna came across as being energetic, outgoing, and also courageous in taking retraining. She had helped to take care of her mother-in-law, but had no other previous experience in the health care field. At the time of the interview, however, Anna was somewhat frustrated with the difficulties of finding a job. She worked on call but was not getting many hours, a situation she attributed to her age.

\section{Findings}

\section{The Impact of ESL-Skills Training on Employment}

\section{Current Employment Status}

The first research question deals with the impact of training on participants' subsequent employment opportunities and status. Most of the participants spoke at length about employment issues, including their current status. At the time of the interviews, which took place one year after the completion of the RCA program and two years after the completion of the HS program, only one of the participants, Alberto (the lone male), had a permanent position. Karen, Magda, and Yin were working on call (25-40 hours) and were satisfied with the number of hours they were getting. Magda and Yin were both enrolled in community college programs to upgrade their qualification, in addition to working almost full time. Anna and Rita were mainly doing HS for less than 25 hours a week and wanted more work. Three of the participants, Fatima, Sofia, and Karina, had been unable to find work in the field. Sofia's and Karina's employment options were somewhat limited because they were graduates of Home Support, whereas most of the participants were working in long-term care facilities as opposed to HS. Consequently, a dominant theme that emerged from the interviews was the existence of numerous barriers to employment even for those with relevant experience.

\section{Challenges Finding Work}

Finding work was difficult for most participants. Some, like Alberto, found that he needed certification to work in HS, which he had done without certification in Montreal. Karina concurred, "I don't have nothing to put on my résumé! I can put only my background, my country's experience ... That experience is not accepting here. You need to have [Canadian] experience, [Canadian] certificate." 
A number of them said that they had applied to many places, but it was hard just to get an interview. This difficulty in finding work or even getting responses to inquiries puzzled several of them, as they had expected that on completion of the program they would have full-time jobs. The importance of learning employment-seeking skills such as résumé-writing and jobsearch was apparent and is an important area for further training (Furnborough \& Munns, 1984; Wilson, 1998). Indeed, given the difficulty of finding employment in this field and in this municipality, effective job-searching skills and strategies (e.g., finding interim volunteer work) were crucial. Fatima spoke about learning not to bring her child with her when applying for a job, which illustrates the importance of understanding the cultural expectations concerning job-searching in Canada in addition to learning the language, skills, and connections needed to look for work: "So when I get the course and when we talk about how we can find a job or something like that, I hear that you don't have to take your baby with you when you apply." She found the employment skills component especially important because of her relative lack of experience:

Even I didn't know how to make the résumé.... Before I come to here, I don't know because just I apply one place, even I didn't put application in Toronto.... My cousin bring me there. Agency said, "Okay, go immediately to work [in] the place." When I go, the owner like me when he see my job. And as soon as I go there, they hire me. I didn't put application or nothing like that. But I learn from ISA.

\section{On-Call Work, Shift Work, and Other Employment Barriers}

The need to work on call, discussed above, was another major barrier for many participants. Alberto said that the program manager and skills instructor explained the necessity to build hours, which he was determined to do:

They call me any shift ... I was ready to go because the teacher ... she told us we have to build hours to have seniority. So I was ready to do any shift. So I said to my wife, "You give me a chance, don't ask me to do nothing, because I need to sleep."

Alberto was able to deal with unpredictable on-call work with the support of his wife and was able to build his hours, which eventually led to a permanent position. But for many of the other participants, being on call was problematic, a waste of time, and an unsteady source of income. As Sofia remarked, "If I even decide to wait for the phone calls, I still need some money to live." Similarly, shift work, which is common in this occupation, is an aspect of work that can adversely affect family and other social life, as it requires participants to work on holidays and weekends, for example. For those with young children, like Karina, the need to do shift work was a major problem: 
They [the employers] asking, "Do you like to live-in or do you like to stay during the night hours?" ... But after 10 o'clock I cannot. I cannot do because my children wants me.... There are three of them under 7 years old.... "Don't go, Mummy, don't go," they say. "Stay with us."

Karen discussed the change in her social life because of shift and on-call work:

Before the job is different, is a lot of change because in the past I worked in the office, for the weekday. But now I need to work, even I need to work on the standard holiday and also, the casual, mostly they work on the weekend.... Yeah, I work for a lot for the weekend.... So it even did affect your family life a little bit.... In the past, whenever at the weekend will be go out. Yeah, you would take a trip to the States or to other place, but now it's hard for you to do that.

Alberto also discussed how shift and on-call work had affected his family and social life, especially on weekends:

We are Catholic so we used to go to church on Sundays. So now it's a little bit change. We only go on Sunday when I'm not working.... And I have to work in the weekends, so that is change my life. I may have day off in the middle of the week. But I find it not difficult because I can spend time with my family. And it's more relaxed, less traffic or wherever we go not too much people.

Thus working as a care aide, often on call or in shifts, can be a deterrent to finding employment and requires adjustments in one's family and social life, although it can also have certain advantages such as a relaxing day off in the middle of the week, as in Alberto's case.

These findings regarding employment prospects and working conditions concur with the observations made by $\mathrm{Ng}$ and Estable (1987), who reported that many immigrant women must be available on a short-term, temporary basis and that their working hours tend to be irregular because of the need to do on-call, shift, and night work. However, because of their role as primary caregivers to their children, the women appeared to be more restricted in their work options than men in the same field.

Other employment barriers included transportation, particularly for those in HS who needed to travel from client to client, often separated by great distances. Anna and Karen both mentioned that some facilities preferred graduates from college programs. And finally, Fatima and Anna felt that personal characteristics such as age or level of education were also barriers to employment. These observations are summarized in Table 2. 
Table 2

Barriers to Employment

1. Lack of certification

2. Difficulties in finding work compared to past experience in Canada

3. Need for contacts/connections

4. Need to work on call and shift

5. Irregularity in number of work hours/ unstable income

6. Family responsibilities: child care

7. Transportation limitations

8 Lack of recognition of ISA certificate/ preference for college care aide certificate

9. Personal characteristics: age, education, level of English, race
Alberto, Karina, Magda

Alberto, Anna, Fatima, Karina

Alberto, Anna, Fatima, Karina

Alberto, Anna, Karina, Sofia

Alberto, Anna, Karen, Magda, Rita

Fatima, Karina, Sofia

Anna, Karina, Sofia

Anna, Karen

Anna, Fatima

The Impact of ESL-Skills Training on Participants' Interactions in Public and Private Spheres

English and General Communication Skills at Work, at Home, and in the Community

This section provides answers to the second research question by examining the impact of completion of the training program on participants' perceived English language and other communication abilities and on their social interactions with people in both public and private spheres. Many of the participants spoke of their improvement in English and how this increased their independence. For Sofia, this was the most important result of participating in the program:

The most important is improve English. I am able to speak. Sometimes I got some problems but I forgot some word. I don't use that much

English, but I can speak... I can go to interview find some job, or in the store.... In the bus, when somebody ask me something ... I can help somebody who don't know English.

Thus Sofia was empowered by her increased ability in English. She could now help others as well as do more things for herself. Fatima commented, "I can write, I can understand everything more than before. I know a lot of words but before I didn't knew." Karina said that her English level went from lower intermediate to upper intermediate: "I can answer better than before. Before I don't understand if you ask something how to give full answer." Karina also observed how learning English increased her independence: 
I know how to search job, because before I don't go. I need somebody. If I go somewhere, I call someone, one of my friend or my husband:

"Come with me, come with me, help me." Because I was backward, I don't have forward by myself. I don't have strongness... Like nervous.

Now I don't have that. I, by myself, I go and ask. I did that every agency last time. Personally I went and talk to the boss, or reception. So it's kind of improvement.

Both oral and written English communication are important in work as a care aide. So too is nonverbal communication and other strategies for communicating with residents with a variety of conditions (e.g., dementia, Alzheimer's disease, aphasia) affecting their speech or hearing. Thus developing a range of practical communication strategies proved essential during the practicum experience and in participants' ongoing work in this field, a point we explore in greater depth elsewhere (Duff et al., 2000). As Yin reflected:

It's useful because many elderly people have dementia or Alzheimer's or confused. Sometimes it's hard to deal with them. If you learn this course, the teacher of this course give you more idea how to deal, how to cope with the people. When you work, it's easy to going on.

The participants' experiences with learning English and other means of communication ties in with language socialization perspectives on the interdependence on language learning, sociocultural knowledge and activities, and the role of social interaction and experience in the development of new language and literacy competences (Duff, 1995; Duff et al., 2000; Li, 2000; Schieffelin \& Ochs, 1986). Thus learning English to search for a job involves not only language, but also cultural scripts and schemata, an understanding of what to say and also whom to say it to, how to go about saying it effectively, and in whose presence, as was illustrated in Fatima's job-search example in the above section. By means of completing the ESL-skills program and pursuing employment opportunities afterward, participants gained knowledge of the linguistic and pragmatic complexities of communicating in English-speaking society and culture(s).

Yet despite their overall sense of having improved considerably in English and in their ability to interact with higher-status officials and service providers, as well as with co-workers and residents, some participants regretted not having more opportunities to use English in their everyday life. Karen commented about the need for more speaking practice, and a number of the other participants said that their English use outside of work and training was still limited. Only Rita said that she had English-speaking friends. For most of the other participants, the use of English was limited to the workplace or with former classmates. Anna talked about how difficult it was to keep up her English skills when she was not in a course or working. 
Alberto also noted his limited English use, in his case exacerbated by working in a Francophone care facility:

Only I have contact with English people when I go to work. Only. So I need more practice. I go to school but it's not enough. I need to have English from British Columbian, to learn the dialect from here.

This point about limited exposure to English speakers or to opportunities to practice speaking their L2 in the workplace or elsewhere confirms Tollefson's (1985) and Ramkhalwansingh's (1981) findings regarding the importance of training programs for immigrant workers to improve their language skills. Other research reports on similar phenomena. For example, Norton (2000) discussed the limited access the immigrant women in her study had to English social networks at work or in the wider community in terms of a "Catch 22"-having limited English also limited a person's inclination to practice speaking English with strangers (or even with more proficient speakers of English from the same L1 group). Both Cumming and Gill (1992) and Norton (2000), moreover, found that even after several years in Canada the women in their studies had not developed friendships (or acquaintances in some cases) with local English speakers, for a variety of reasons. Hence the experiences of participants in this study are not atypical in that regard. Indeed, even at work in an ostensibly English-language workplace, opportunities to use English may be limited. Yin, Karen, and Fatima, for example, commented on the predominance of a language other than English in some workplaces. We reported on the growing phenomenon of multilingual workplaces in our larger study as well, providing examples of certain care facilities where a majority of residents did not speak English, as in the case of an urban hospital with large numbers of elderly Toisan Chinese (see also Goldstein, 1997).

The impact of the program and greater ESL proficiency in particular on family and community life also became evident. For example, Karina could now help her son adjust at school better:

It's helping me to talk, to communicate with the teachers and the parents.... My second son, he doesn't talk much, he's so shy, $y^{\prime}$ know.

Until six months he didn't talk to the teachers. He didn't talk to the other children. So teacher called me, and she asked me to come for one hour, to stay in class. After, then he start to talk.

Instead of the children serving as their cultural and linguistic translators in an unavoidable role reversal, the parents were now better able to fulfill their public parenting roles that required English. Fatima gave another interesting example of how her participation in training had benefited her son. While she attended the New Start Program, a pre-employment program offered by ISA for immigrant women who are survivors of abuse, and for nine months 
afterward she received a day care subsidy. Her son was in day care for about two years, and there he learned to speak English. "Now he can talk my language and English too.... If I didn't go that course, even my baby can't talk English." She also taught him to write in English. Similarly, Sofia talked about how her knowledge of English had affected her relations with her children: "At home, I can understand what my children saying between them because they doesn't want so much to speak Polish." Therefore, for individuals like Fatima and Sofia, participation in this skills and language training program had a beneficial impact on their caretaking roles and status at home as well as on their intergenerational family communication. This is an interesting point in the light of research on relationships between immigrant mothers and their children and how divisive it can be when either the mother cannot speak English and the children do not want to or cannot speak the home language or when mothers become dependent on their children to translate for them (Kouritzin, 2000; Wittebrood \& Robertson, 1991; Wong Fillmore, 1991).

\section{Health Care Expertise and Status in Family and Community}

Anna and Karina both discussed the significance of their knowledge of health care in their ability to help or advise their family members. Anna said, "I tell my boy, always tell him to go see the doctor... You have to keep yourself healthier, build up your body so when you're getting old, you don't have to worry about too much disease." Karina voiced a similar perspective about the health care knowledge she acquired in the program:

It's help for us to know the health knowledge. And we can advise our family, don't do this, it's not good for your health, like kind of smoking or eating some unwanted food. And some they stay with the sick for a long time. They don't go to hospitals. They don't go to doctors. So we can advise them: Soon you go to hospital and get it clear, or otherwise you will get worse and worse. Some of our parents or grandparents they never go to hospital. They stay with the sick, like diabetic, or like, $y^{\prime}$ know, kind of pains. They suffer with that, but they don't like to go to the doctors. They don't believe them. Yeah, so we can advise them. It's better to go to the doctor and get medication and get well.... So it's a good knowledge for us.

Thus although several of the women in this and the larger study had previously provided care to elderly relatives, they now had a better sense of both practical and medical aspects of health care, knowledge that had a positive impact on the physical health of their family members. This description of Karina's also revealed that she was a bridge between the home culture and the mainstream culture, for example, regarding doctors and hospitals and the treatment of illnesses. 
Increased health care knowledge and ability in English also had direct effects on some of the participants' ability to care for their children in the public sphere. Sofia gave an example related to her ability to access medical services: "I am able to go with my children to the doctors, to the ophthamologist, to the dentist, to the different kinds of doctors. And I understand what they saying."

The above examples show the positive effects of participation in the training program, some of which have also been discussed elsewhere. Giles (1987), for example, discussed how the lack of English proficiency affects a woman's relationship with her children and with the education and medical systems. Conversely, an improved knowledge of English and health care improved the ability of women in this study to take care of their family. Other positive aspects of working as a care aide were evident. For example, being a professional caregiver also transformed Alberto's practices in his personal domestic sphere with his wife and two infants. He recalled:

I am feeding them, the old people [at work]. So when I go home, my children sometime they don't want to eat. So I say, if I feed the old people, how come I don't feed my children? ... Then I feed them too.... Sometime I cook for all of them.... I cook for all of them and then feed them.

In summary, the participants benefited from the language and skills training program by improving their English and learning nursing skills of use in their own homes as well as in the wider community.

\section{The Impact of Training and Employment on Participants' Identities and Settlement}

The third research question dealt with the impact of participation in a training program on the participants' identities and settlement in Canada: Some identity issues related to participants' desire to become a care aide and the personal satisfaction derived from learning new skills and becoming a professional caregiver were discussed above. Here we deal with a broader range of topics related to the third research question. We examine the impact of training on individuals' overall wellbeing, including their self-confidence and self-esteem, self-development, and settlement.

Becoming "Somebody": (Re)Gaining Confidence, Self-Esteem, and Autonomy

The need to do something meaningful, to make a contribution to society, to "be somebody," and to have a sense of personal growth and accomplishment is a theme that Rockhill (1991) explored in her study of immigrant women in Los Angeles. Taking part in and successfully completing the program was a significant achievement for Sofia and contributed to her positive feelings of 
self-worth and identity. This desire for and attainment of new abilities and identities following immigration may also be important in the settlement process; that is, having a meaningful occupation can give immigrants a greater sense of autonomy and confidence in their ability to contribute to the wider society, which may help them to feel more a part of that society. Sofia's increased knowledge of English affected her interactions at home and in the public sphere. She was able to interact with people in the medical system and was even able to help others who did not have the English skills she now had. Although Sofia had not yet found work in the field, taking the course itself was worthwhile and rewarding, regardless of whether it improved her employment prospects:

It was the decision very important in my life, to go to school.... I was feeling at that time I need to do something with me. I can't clean all the time, especially if I had some ability to care, from Poland and basically all my life... It remind me that knowledge, what I had before, from Poland, about medical care... I feel good about my achievement.... My self-esteem, it was going up. So I'm happy I finished.

She continued, "If somebody wants to improve English, improve his knowledge about this field, and they need to do something, like me, just like me, why not? It's very helpful."

The ability to complete the program was an important achievement for a number of the other participants, especially those who had faced some barriers. For example, both Anna and Rita had felt somewhat disadvantaged because of their age and lack of postsecondary training. For both, successful completion of the program significantly increased their confidence and selfesteem. Payne (1991) and Sensi (1992) also reported on the increase in confidence among women who participate in training programs. Anna described her ability to overcome barriers, which involved not only learning enough English and nursing to obtain a certificate, but also convincing her husband that she could do so:

Every day when I come home, I study two hours... My husband said, "I don't believe." Nobody believe I can pass. And that time is hard for me, but I think after that, when I get the certificate, I'm happy because I can get it.

Rita also described a similar sense of accomplishment and increased confidence:

As I am old, I can tell you I am old. I have four children and I didn't go to college or universities, and when I took this course, I didn't think that I could do it. But during the course, I developed confidence and the teachers are very nice, instructors, ESL teacher, the project manager, they're very good, gives you more confidence in yourself. 
This comment also reinforces how important it is for program instructors and administrators to be aware of the special needs of immigrant women who are retraining (Payne, 1991). In the case of Karen, finding out that she was capable of doing the job was important for her as she was making a major change in occupation by entering the health care field:

Before I get this job, even for me when I studied, when I still studying this course, I just have question: Can I adapt this kind of the job? But after I get the job, I find that I can do it. So now I'm quite happy.

Rita, a Filipina in her late 40s, spoke about finally having her own place and being able to manage financially on her own:

I have my own place now. Even though I have a roommate, still consider, you know, if you have your own room and stuff like that. And financially, I can provide or you have to budget yourself ... to pay the bills.

Increased confidence was in many cases connected to the ability to find and keep a job. Sofia was a special case in that she gained much from the course alone, but for most participants, having a job was also vital to their self-esteem and confidence. Even Sofia said that it would be even better if she could find a job. The importance of employment was particularly evident in Fatima's case, as she had been unable to find work despite many months of volunteer work. She observed, "My education is better, but my life is no change. Maybe when I get a job, I feel confident."

But low self-esteem was not something that only the women participants in this study had experienced. Alberto also talked about his increased self-esteem and sense of wellbeing resulting from program completion and from finding a job. He saw gradual improvement in his life and in his ability to take care of his young family.

The change now is that I feel happy because I have a job. I don't have a full-time job officially. Almost. But I think that my mind still is functioning good.... First of all I was in unemployment insurance ... then I went to welfare, but now I am working. Welfare is only a guarantee. In the meantime we can find something to feel the self-esteem, you know, that we have power. We can do the things we want in order to pay my rent by myself.

\section{Settlement and Integration into Canadian Society}

Taking the training program also facilitated settlement and integration into Canadian society for some of the participants, as in the case of Sofia. A central theme for Yin was the importance of learning English in her settlement process: "Most of the time, I feel confident... Before I was scared because I didn't speak English." Other participants also spoke about the importance of learning English and having contact with English speakers for 
settlement and integration into Canadian society. For Karen, entering the health care field was a way to "get into the mainstream" and to become more integrated in society. She spoke about how she did not want to be limited to her own ethnic community:

I stick in my our own culture, so it's difficult for you to expose yourself.

Expose yourself, that means to integrate to the Canadian people... The

place I work is with white people or also with the different kinds of

people, so I got many chance to speak the English. So I think it's better.

A recurring theme was the importance of speaking English in the workplace as a way to integrate more fully into Canadian society, as this is mainly where immigrants have contact with English speakers. As we noted in connection with the second research question, however, even finding opportunities to use English at work was challenging. Karen had turned down a full-time position in a Chinese care home and opted for casual work at two "Western" facilities because of the importance of integration. Yin was upset with her co-workers because they made little effort to speak English as most of them had a common first language. Anna also spoke of the importance of speaking English at work: "I think I'm lucky because I work with Canadian people. I speak English. I have to."

\section{Developing a New (or Renewed) Professional Identity}

Other participants also spoke of their increased confidence and self-esteem, connected closely with gaining or renewing their professional identity. Magda, for example, described how further training in nursing helped her adapt to the Canadian health care situation:

After the program I'm confident, confident to do the job.... Nursing in the Philippines, nursing in Saudi Arabia, and nursing in here have some differences, so the course really helped me because in that course, I have learned how is nursing in $B C$ which is also different what I did as a nurse in Saudi Arabia and in the Philippines.

Having confidence in her ability to work as a nurse was especially important to Magda, whose life and identity were so much wrapped up with the nursing profession. Her statement also draws attention to the importance of understanding local occupational practices, even for those with previous experience.

\section{Other Personal Transformations}

Many derived intense personal satisfaction from being a care aide, helping and caring for others. Anna commented, "When I feel somebody when they holding me, they thank me, oh, I think I am useful.... I'm really glad." She also described how this work had transformed her, not only in learning to 
care for the elderly, but also as one of the older participants in the group facing her own future:

Before you never know how much kind, those kind of sickness in the old people. You know they are old and they mumble all the time. When you know them, it's okay, but if you don't know them, oh my god, too much noisy, right? And it's, oh my god, how come they bother me all the time, right? But now you know it's because they are lonely. And the sickness. They need you, even you keep her company. You don't have to do anything. You just sit down to talk to them, holding their hands, they feel great. And I feel that way when I was lonely sometime. When I'm sick, I want somebody to keep me company. And I found out like, nowadays, it's like, you have to think about that's your future. Like before, you never think about that. I'm still young. I don't have to think about that. So nowadays, when I see any kind of people, I will love them.

Therefore, taking the language and skills training program and working as a care aide had a significant impact on the individuals on a personal as well as a professional level. Successful program completion, improved English (i.e., official language skills), and increased autonomy in turn enhanced participants' self-esteem, confidence, settlement, identity, and integration into wider society (Giles, 1987; Tollefson, 1985). Also extremely important was the ability to find employment, to put language and nursing skills to use, and to be able to provide for oneself and one's family. Last, working as a care aide also gave participants personal satisfaction and an important sense of their contribution to society. Table 3 summarizes the main findings regarding the beneficial impact of the training program and employment as a care aide on the participants.

Table 3

Benefits of Training Program and Employment as a Care Aide

1. Improved English skills: increased confidence, autonomy, and independence

2. Acquired occupational skills

3. Acquired employment skills

4. Increased knowledge of health care: positive effect on family life

5. Facilitated settlement/integration into Canadian society

6. Increased self-esteem
Anna, Fatima, Karina, Sofia, Rita, Yin

Karen, Magda, Yin

Fatima, Karina, Magda

Anna, Alberto, Karina, Sofia

Alberto, Karen, Karina, Sofia, Yin

Alberto, Anna, Karen, Karina, Magda, Rita, Sofia 


\section{Discussion}

Completing the program described in this article and working as care aides had a major impact on the individuals' English language ability, which increased their independence and confidence and facilitated their ongoing settlement and integration in Western Canada society. However, finding employment was problematic for many of the participants, who identified a number of barriers to obtaining employment as a health care aide. Some of the themes concurred with previous studies on immigrant women and training, whereas others have not been discussed in the literature in depth and thus need to be further explored. Whereas previous research has focused on barriers to access to education and training programs, in the present study barriers to employment were of greater concern, as all the participants had been fortunate in overcoming barriers to program access, and all had successfully completed the program. ${ }^{3}$

A major theme was barriers to employment as a care aide. It is often naturally assumed that access to training programs leads to better employment opportunities, among other benefits. However, although taking the program did facilitate finding employment in the health care field, participants in this study spoke at length about the barriers to finding satisfactory employment as a care aide. Only one of the participants, Alberto, had a permanent position. Most of the women were still working on call one year after finishing the program; some were satisfied with the number of hours they were working, whereas others were not. Three people had not yet been successful in finding employment as a care aide. Some of the barriers to employment were similar to the barriers to access reported in the literature, for example, child care and other domestic responsibilities, and transportation. Other barriers specific to finding employment, for example, were a lack of local experience and local contacts. Others may be industry-specific, for example, the need to work on call in order to build hours and develop seniority. Given the difficulty of finding work, a number of the participants spoke of the helpfulness of employment training, for. example, learning job-search skills.

Additional themes that arose in this study that support previous findings include the positive impact of participation in a training program on occupational and language skills. For most of the participants, getting training and obtaining a certificate were important precursors to entering the health care professions. Both participants with overseas qualifications and those pursuing a new occupation spoke of the importance of certification that was recognized in this province. The local skills training also gave them confidence in their ability to do the job in the Canadian context. Also important is the development of an occupational identity (Eastmond, 1993) and improved English skills for participants' growing independence, self-con- 
fidence, and integration into Anglophone-dominant society. Improvement in English helped participants in both the public and private spheres. In the public sphere they could look for employment on their own and deal with medical and educational systems that enabled them to take care of family members better. Improvement of English also affected the private sphere, for example, by increasing the individuals' self-confidence, self-esteem, and autonomy.

Affective barriers related to language ability and social identity (as perceived by oneself and/or imposed by others), as others have also observed (Arnold, 1999; Li, 2000; Norton, 2000), may prevent otherwise confident, capable, and independent individuals from participating more fully in English-mediated public life and social networks. Immigrant women who lack knowledge of an official language are often isolated (Giles, 1987) and prone to a variety of conditions stemming from adaptation stress that may be difficult to remedy because they do not feel comfortable seeking outside social support services (Wittebrood \& Robertson, 1991). However, developing English skills and contacts must be balanced with maintaining L1 social network ties and other aspects of their L1 cultural identities, histories, and support systems, as was reported in Rockhill's (1991) study of Hispanic women in California and Goldstein's (1997) study of Portuguese-Canadians. Both of these studies identified the importance of L1 use among co-workers from the same ethnolinguistic backgrounds as a way of maintaining highly valued in-group ties and support (as well as being an efficient way of completing time-sensitive work on production lines in the latter study). Yet these L1 networks can also prolong participants' isolation from English-speakers, despite their desire to move out of language and lower-tier job "ghettos."

\section{Implications for Further Research and Training Program Delivery}

Because of the exploratory nature of this study, it has raised issues in a number of different areas. One major area for further research is employment barriers for those who have successfully completed training and how such barriers can be reduced. Related to this topic is the teaching and learning of employment-finding skills, which appeared to be an important aid to the participants in this study. More research is needed to examine how programs can better prepare their clients to find employment and to determine what kinds of post-training support (e.g., in job-seeking strategies, conversational English) would also be beneficial. Both qualitative and qualitative research, for example, a combination of in-depth interviews and questionnaires or surveys, could be used to increase our understanding of the types of jobsearch skills that are most useful to immigrants and to examine how those who have been successful in finding work did so. In addition, research 
focusing on changes in participants' employment status, personal and professional identities, language abilities (or socialization), and their integration in Canadian society must take a longer view, as changes in these areas may take many years. Therefore, longitudinal research over many years (and not just a few years, as in this study) may be necessary. Similarly, research that examines immigrants such as Anna who have lived in Canada for decades but are only now moving into different types of work and different levels of English and thus integration into society would be timely and helpful.

Although not the focus of this article, in terms of program delivery further research is needed into the integration of occupational language and skills components of the program. The central issue is how best to help immigrants meet their vocational language needs while also attending to their more general language needs. Situational studies in care facilities could give valuable insight into the language needs of care aides. Duff et al. (2000), for example, on the basis of participants' self-reported clinical experiences, determined that care aides required a broad range of communication skills and not just medical or technical English; everyday English for social purposes and nonverbal communication skills were also vital. Indeed, Duff et al. found that residents in one particular institution (an urban hospital) themselves did not speak English and had various conditions associated with aging (e.g., deafness, blindness, Alzheimer's, dementia, aphasia) that required the extensive use of nonverbal communication and other strategies by caregivers. Therefore, an ethnographic approach, as used by previous researchers in second language studies (Holliday, 1995; Roberts et al., 1992) would provide a more holistic understanding of the relationship between language use, social interactions, and the culture of different care facilities. It would also be helpful to interview residents and various staff members in order to get multiple perspectives on the language needs of care aides and on communication processes and problems more generally. Although it was not a factor in our larger study, one former nurse educator working with immigrant health care workers in the area (Corrigan, personal communication, 2000) reported that discrimination and verbal abuse among elderly Englishspeaking residents in such facilities toward immigrant caregivers (especially women) can be a major problem. Thus ways of helping vulnerable workers deal with such attitudes and treatment must also be explored through research and the development of practical intervention strategies.

Another area for further research is the impact of training and employment on self, family, and settlement in this and other types of programs. This study has merely touched on issues in one occupational and language training program with a relatively small number of participants who were interviewed just once each. More in-depth longitudinal interviews with participants and perhaps their family members and colleagues would permit 
a deeper analysis of the complexities of employment and settlement for immigrants. Finally, this study included immigrant women primarily, for reasons that are described, and the accounts of the women in this cohort revealed just how long, arduous, and uncertain a process it can be to learn English and find gainful employment in Canada. It would be helpful to learn more about the experiences of immigrant men in this and other kinds of training and employment to understand better what gender- and occupation-based differences might exist in their experiences before, during, and after such programs. Further research in all these areas will provide a more complete understanding of the impact of skills and language training programs on immigrants' lives.

\section{Conclusion}

The question "What difference does it make?" is often asked in relation to ESL program evaluation and "outcomes" studies, particularly programs that are publicly funded. Although our research was not designed as an evaluation, the questions we asked about the impact of the programs on participants' lives were clearly designed to explore the differences language and skills programs make in the lives of ESL speakers from a variety of geographical, linguistic, and vocational or professional backgrounds. For the individuals in our study, we found that participating in language and skills programs made an enormous, albeit not easily quantifiable, difference. To have been given the opportunity to continue to learn, to obtain marketable skills, to meet new people, to feel like valued individuals with something worthwhile to offer society, and to gain confidence in English language use that extends far beyond the realm of language for work are benefits that have a ripple effect: a growing sense of self, value, competence, and wellbeing in turn has a positive impact on members of participants' immediate families, communities, and society.

However, this study has also revealed that participating in and successfully completing programs is not a panacea. It is just part of a long, difficult process of acculturation, adaptation, socialization, and negotiation that continues on a daily basis as immigrants struggle to find satisfactory work, interact with co-workers and residents, and juggle the personal and professional demands and stresses of modern life and sometimes discrimination as well, often without the support of local extended families or other help. That is, measuring the effectiveness of programs by examining immediate employment outcomes-especially in this field-may not reveal the incremental benefits and experiences that may accrue from language learning and vocational or professional training or the challenges and joys of moving from blue-collar (particularly factory) work to more public, service-sector positions. Yet until graduates succeed in finding satisfactory employment, and especially women whose employment may be delayed or complicated 
by other factors, additional government or agency support may be required. But according to Lee (1999), agencies (such as ISA) funded to assist with immigrant settlement and training "tend to view immigrant women through a conservative traditional lens that locates women in the family" (p. 61). That is, rather than provide support to women workers or aspiring workers, they tend to provide greater support to immigrant women

in their domestic roles as mothers and wives, a view which delimits and overlooks other roles and identities of immigrant women. While there is a large unmet need among non-English speaking immigrant women who are house-bound with young children, the overwhelming perception of immigrant women in their maternal roles in the family ignores other roles they occupy in society such as worker, entrepreneur, citizen, student, activist and consumer of services. This supports and perpetuates traditional images of immigrant women as isolated, dependent on men and burdened with children. (p. 61)

In addition, although the study revealed the many benefits of participation in such programs for populations who have traditionally been considered at potential risk in Canadian society (particularly immigrant women with low-level English skills), programs like ISA and their highly committed and competent personnel themselves are constantly at risk of government funding cuts or elimination, and they must operate on a year-to-year basis (Lee, 1999). However marginal participants may feel vis-à-vis mainstream society, ESL program personnel may feel equally vulnerable in employment structures such as these that provide little security, little planning and preparation time, and few extended employment benefits. In the program we investigated, for example, there was major staff turnover in a period of just two years, with only one person remaining out of the four staff members who participated in this study. Their reasons for leaving varied, but an overriding sense of job pressure and the lack of job security and benefits prevailed. Thus it is incumbent on ESL professionals to become advocates for such programs and provide evidence of the short-term and longer-term human benefits of participation to individuals and society, as well as the ongoing barriers to successful employment, the need for extended program supports for individuals until they secure full-time employment, and the need for funding agencies to see the value of language-skills programs and to invest in them and their workers accordingly.

Immigrants have often been perceived as a disadvantaged group in Canadian society and, despite the great heterogeneity among people classed as immigrants, the literature suggests that collectively they do face many barriers in their settlement and integration. However, this study also revealed the inner strength, perseverance, and commitment of one group of immigrants learning ESL and skills in (and following) training programs, 
and their ability to inspire others by their courage, determination, and compassion. Immigrants such as these display both the potential and the deep desire to contribute to Canadian society in yet untold ways-if only they are given the opportunity and the necessary support to do so.

\section{Notes}

${ }^{1}$ In general, the face-to-face interviews were longer than telephone interviews. The longest interview took place in a participant's home, where the atmosphere was more informal and conversational in tone. Because the interviewer (Ping Wong) was a Chinese woman from an immigrant family and an ESL teacher at ISA (in a different program area), the participants may also have felt more comfortable than if they had been interviewed by researchers more removed from the ISA context.

${ }^{2}$ Excerpts are not edited for grammar; however, some excerpts have been shortened for reasons of space and clarity, as indicated by ellipses.

${ }^{3}$ Nevertheless, a number of them reported on their difficulties initially finding a training program that was accessible to them as a result of such factors as high costs, long waiting lists, and the need for a certain level of proficiency. The training programs at ISA were governmentfunded though, and this had reduced the barrier of cost. In addition, depending on the funding criteria, some financial support was offered (e.g., transportation and training allowances). ISA also tried to facilitate participation by offering combined skills and language training programs; thus the language requirements for their programs were not as high as for college programs. Because ISA offered the RCA program only once a year, some participants did have a long wait, whereas others seem to have applied at the right time and did not have to wait long for the program to begin. In addition to these main barriers to access, some of the participants also spoke about internal (psychological) barriers to successful completion of the program such as selfschool incongruence and low self-confidence (Hayes, 1989). Several of the participants attributed their success in the program to the encouragement and support of the instructors and the project manager.

\section{Acknowledgments}

This research was funded by a Hampton grant from the University of British Columbia. We wish to acknowledge and thank our research participants and colleagues at ISA for their cooperation in this study, and our reviewers for their suggestions on an earlier version of this article.

\section{The Authors}

Ping Wong (MA, UBC) has taught ESL and EFL in a variety of contexts in Taiwan, Germany, Vancouver, and Toronto. She has worked with adult immigrants in a number of language and skills training programs and is currently teaching EAP at the Seneca College English Language Institute in Toronto.

Patricia Duff is an associate professor of language and literacy education at the University of British Columbia. Her research interests include language socialization in multilingual educational and professional settings; activity theory and classroom task-based discourse analysis; and qualitative research methods (ethnography and case studies).

Margaret Early is an associate professor in the Department of Language and Literacy Education at the University of British Columbia. Her research interests include language socialization in multilingual, multicultural school and workplace settings and teacher education.

\section{References}

Arnold, J. (Ed.). (1999). Affect in language learning. Cambridge, UK: Cambridge University Press. 
Bell, J.S. (2000). Literacy challenges for language learners in job-training programs. Canadian Modern Language Review, 57, 173-200.

Boyd, M. (1992). Immigrant women: Language, socio-economic inequalities, and policy issues. In B. Burnaby \& A. Cumming (Eds.), Socio-political aspects of ESL (pp. 141-159). Toronto, ON: OISE Press.

Burnaby, B. (1992). Official language training for adult immigrants in Canada: Features and issues. In B. Burnaby \& A. Cumming (Eds.), Socio-political aspects of ESL (pp. 3-34). Toronto, ON: OISE Press.

Cumming, A., \& Gill, J. (1992). Motivation or accessibility? Factors permitting Indo-Canadian women to pursue ESL literacy instruction. In B. Burnaby \& A. Cumming (Eds.), Socio-political aspects of ESL (pp. 241-252). Toronto, ON: OISE Press.

Duff, P. (1995). An ethnography of communication in immersion classrooms in Hungary. TESOL Quarterly, 29, 505-537.

Duff, P., \& Labrie, N. (Eds.). (2000). Languages and work. Special issue. Canadian Modern Language Review, 57(1).

Duff, P., Wong, P., \& Early, M. (2000). Learning language for work and life: The linguistic socialization of immigrant Canadians seeking careers in healthcare. Canadian Modern Language Review, 57, 9-57.

Eastmond, M. (1993). Reconstructing life: Chilean refugee women and the dilemmas of exile. In G. Buijs (Ed.), Migrant women: Crossing boundaries and changing identities (pp. 35-54). Oxford, UK: Berg.

Frank, R.A. (2000). Medical communication: Non-native English speaking patients and native English speaking professionals. English for Specific Purposes, 19, 31-62.

Furnborough, P., \& Munns, R. (1984). Communication for employment and training. ESP Journal, 3(2), 97-108.

Gee, J.P., Hull, G., \& Lankshear, C. (1996). The new work order: Behind the language of the new capitalism. Boulder, CO: Westview Press.

Giles, W. (1987). Language rights are women's rights: Discrimination against immigrant women in Canadian language training policies. Resources for Feminist Research, 17(3), 129-132.

Goldstein, T. (1994). "We are all sisters, so we don't have to be polite": Language choice and English language training in the multilingual workplace. TESL Canada Journal/Revue TESL du Canada, 11(2), 30-45.

Goldstein, T. (1997). Two languages at work: Bilingual life on the production floor. New York: Mouton de Gruyter.

Harper, H., Peirce, B., \& Burnaby, B. (1996). English-in-the-workplace for garment workers: A feminist project? Gender and Education, 8(1), 5-19.

Hayes, E. (1989). Hispanic adults and ESL programs: Barriers to participation. TESOL Quarterly, 23, 47-63.

Holliday, A. (1995). Assessing language needs within an institutional context: An ethnographic approach. English for Specific Purposes, 14(2), 115-126.

Jackson, N.S. (1991). Skill training in transition: Implications for women. In J. Gaskell \& A. McLaren (Eds.), Women and education (2nd ed., pp. 351-370). Calgary, AB: Detselig.

Katz, M.-L. (2000). Workplace language teaching and the intercultural construction of ideologies of competence. Canadian Modern Language Review, 57, 144-172.

Kouritzin, S. (2000). Immigrant mothers redefine access to ESL classes: Contradiction and ambivalence. Journal of Multilingual and Multicultural Development, 21, 14-32.

Lee, J. (1999). Immigrant settlement and multiculturalism programs for immigrant, refugee, and visible minority women: A study of outcomes, best practices and issues. Report submitted to the British Columbia Ministry Responsible for Multiculturalism and Immigration. Victoria, BC: University of Victoria. 
Li, D. (2000). The pragmatics of making requests in the L2 workplace: A case study of language socialization. Canadian Modern Language Review, 57, 58-87.

$\mathrm{Ng}$, R., \& Estable, A. (1987). Immigrant women in the labour force: An overview of present knowledge and research gaps. Resources for Feminist Research, 17(3), 29-33.

Norton, B. (2000). Identity and language learning: Gender, ethnicity, and educational change. Harlow, UK: Pearson.

Payne, J. (1991). Women, training and the skills shortage: The case for public investment. London: Policy Studies Institute.

Platt, E. (1993). Vocational/VESL teacher collaboration: Some substantive issues. English for Specific Purposes, 12(2), 139-157.

Roberts, C., Davies, E., \& Jupp, T. (1992). Language and discrimination: A study of communication in multi-ethnic workplaces. New York: Longman.

Rockhill, K. (1991). Literacy as threat/desire: Longing to be SOMEBODY. In J. Gaskell \& A. McLaren (Eds.), Women and education (2nd ed., pp. 333-349). Calgary, AB: Detselig.

Rockhill, K., \& Tomic, P. (1994). There is a connection: Racism, hetero/sexism and access to ESL. Canadian Woman Studies, 14(2), 91-94.

Ramkhalawansingh, C. (1981). Language and employment training for immigrant women. Canadian Ethnic Studies, 13(1), 91-96.

Sensi, D. (1992). Equal opportunities and vocational training: Evaluation of in-company vocational training for zoomen. Luxemburg: Office for Official Publications of the European Communities.

Schieffelin, B.B., \& Ochs, E. (1986). Language socialization. Annual Review of Anthropology, 15, 163-191.

Stapp, Y.F. (1998). Instructor-employer collaboration: A model for technical workplace English. English for Specific Purposes, 17(2), 169-182.

Svendsen, C., \& Krebs, K. (1984). Identifying English for the job: Examples from health care occupations. ESP Journal, 3, 153-164.

Tisza, M. (1997). Accessing language resources: A study of the enabling elements of an ESL program for immigrant women. Unpublished master's thesis, University of British Columbia.

Tollefson, J.W. (1985). Research on refugee resettlement: Implications for instructional programs. TESOL Quarterly, 19, 753-764.

Wilson, S.M. (1998). An evaluation of a long term care aide/ESL program. Unpublished master's thesis, University of British Columbia.

Wittebrood, G., \& Robertson, S. (1991). Canadian women in transition. Canadian Journal of Counselling, 25(2), 170-182.

Wong, F.P. (1998). The impact of training and employment as a healthcare aide on immigrants' lives. Unpublished master's thesis, University of British Columbia.

Wong Fillmore, L. (1991). When learning a second language means losing the first. Early Childhood Research Quarterly, 6, 323-346. 